\title{
Impact of a Postcollege Service-Learning Year: From Self to Social Justice
}

\author{
Kelly S. Hall \\ Walden University \\ Cheryl H. Keen \\ Walden University
}

\begin{abstract}
Recent college graduates in the United States are increasingly pursuing a year of service in programs such as Teach for America, AmeriCorps, and Volunteers Exploring Vocation. A cohort of 689 volunteers participating in 18 Volunteers Exploring Vocation programs across the nation was surveyed both at the beginning and end of their year of service. Principal component analysis was used to analyze the two surveys. Repeated measures captured volunteers' motivations for entering the programs and opportunities important to them upon exiting programs. Upon entering, program participants were motivated by opportunities for discovery about themselves in relation to community and for exploring spirituality and careers, but were not anticipating friendships and social life as central to their volunteer year. Important to volunteers at the end of the year were opportunities to express compassion, to gain skills while working for social justice, and to explore careers in the context of friendships and social life. Consideration of these findings may increase the number of emerging young adult professionals who find meaning and purpose in their careers as agents for positive social change and social justice on behalf of communities in need.
\end{abstract}

Keywords: college graduates, service learning, social justice, motivation, dialogue, volunteers

\section{Introduction}

The first year or 2 after college graduation can bring a loss of community and support needed for continuing exploration of one's vocation and purpose. Alumni rely in part on their first postcollege work settings to replace dialogue and reflection with college peers and faculty, which are so conducive to growth during college (Astin, Astin, \& Lindholm, 2012; Magolda, 2009; Mitchell et al., 2015). The lack of meaningful work and family responsibility can postpone adulthood until the late 20s in emerging adults (Arnett, 2014). Seeking meaningful work, dialogue, and reflection, some recent college graduates in the United States have sought a postcollege year of service in growing programs such as Teach for America, AmeriCorps, and Volunteers Exploring Vocation (VEV). For example, AmeriCorps applications jumped 62\% between 2009 and 2011, with more than 582,000 applications in 2011 (Voices for Service, 2012).

Postcollege service-learning programs may represent an extension of the college experience in which increasing numbers of students are engaged in experiential learning opportunities that can facilitate growth by presenting opportunities to overcome challenges and providing settings for dialogue about meaning, purpose, and vocation. Programs for the Theological Exploration of Vocation sponsored by

We have no conflict of interest regarding this research and publication. We were previously evaluators of the program, but no longer are so employed. The Forum for Theological Exploration is aware that we are publishing results of surveys.

Please address queries to: Cheryl H. Keen, Walden University. Email: cheryl.keen@mail.waldenu.edu 
the Lilly Endowment, Inc. (www.lillyendowment.org) are but one example of postcollege servicelearning programs (Richard, Keen, Hatcher, \& Pease, 2016). Postcollege service in a setting that requires reflection is similar to college cocurricular service-learning opportunities. Like cocurricular service-learning, college graduates may seek additional experiences that immerse them in communities where they can further discern how they might align their skills and callings with needs of communities. These motives can become more salient for them as they mature in their understanding of the systemic changes needed to bring about social justice and they may choose to explore such interests before embarking on expensive graduate study (Campbell \& Zegwaard, 2015; Crews, 2013; Keen \& Hall, 2009; Mitchell, Battistoni, Keene, \& Reiff, 2013; Zegwaard \& Coll, 2011).

Many research studies, including several meta-analyses, have demonstrated the influence of service learning on academic, social, and developmental learning during college years (Bowman, 2011, Celio, Durlak, \& Dymnicki, 2011; Conway, Amel, \& Gerwien, 2009; Warren, 2012). Although recent college graduates may find postcollege service-learning programs attractive and a bridge to their future, little is known about full-time service outside of educational oversight. Yet two studies found longterm positive impacts of serving in the AmeriCorps program (Corporation for National and Community Service, 2008; Ward, 2014).

Additional research about a year-long service-learning program may benefit three groups: recent college graduates, college advisors, and service site administrators. Recent college graduates can gain from understanding a third postcollege path distinct from job and graduate school paths.

College advisors who are more knowledgeable about postcollege year of service programs can suggest these programs as suitable postcollege options. Volunteer site administrators who better understand their volunteers' motivations and desired opportunities might better meet members' needs. Such increased understanding may increase the number of emerging young adult professionals who find meaning and purpose in their careers as agents for positive social change and social justice on behalf of communities in need.

\section{Literature Review}

This study is guided by two themes: the impact of postcollege work and year of service programs and the dynamics of emerging adults' development.

\section{Impact of Postcollege Work and Year of Service Programs}

Yearlong service-learning programs share similar goals: Programs place young adults in work settings where they explore the relationship between meeting community needs and their own vocational and leadership development. Postcollege programs offer an opportunity for emerging adults to build skills, while providing a community of dialogue in which to reflect upon vocation beyond the college years (Keen, 2010a). Murphy, Blustein, Bohlig, and Platt (2010) found emerging adults sometimes lacked dialogical vocational support in their first job. In their qualitative study of employed emerging adults, they found that emerging adults' postcollege adjustment left them with frustrations regarding the steep learning curve toward attaining independence, finding meaningful work, and discovering a sense of self-efficacy and concluded that emerging adults need social support in work-based learning programs. Campbell and Zegwaard (2015) found that moral agency and professional identity were enhanced by such supportive work-based learning experiences during the later years of college. 
The postcollege years have been an aspect of Magolda's (2004, 2008, 2009) ongoing research on college students' development. Having interviewed the same emerging adults during and after college, Magolda (2004) found that the year of work after college contributed to young adults' cognitive, social, and relational development toward self-authorship. Although Ward (2014) completed an 8-year study of AmeriCorps volunteers, many of whom entered in the year after college, and found an increase in commitment to public interest and civic awareness, not enough is understood is the developmental influence of postcollege service-learning or volunteerism.

\section{Dynamics of Emerging Adults' Development: Search for Meaning}

The years immediately following college have been identified as a critical time to continue career exploration and find meaning in work while perhaps seeking to respond effectively to the needs of communities. Arnett's (2000) initial interviews and subsequent national Clark University Poll of Emerging Adults (Arnett \& Schwab, 2012) of 1,009 18- to 29-year-olds posited emerging adulthood as a new sociological stage of life that focuses on, among other factors, identity exploration, exploring careers, as well as feeling in-between - the instability of moving through several jobs and roles. Arnett (2014) also found emerging adults to be "self-focused without being selfish" (p. 159), seeking to do some good work in the world. Parks (2011) similarly found, through interviews, that young adulthood is a time of searching for meaning by exploring "big questions" in forming "worthy dreams" (p. 13). Having found this search for meaning to stretch across ages 18-32, Parks also used Arnett's $(2000,2004)$ terminology of emerging adult. Parks suggested that young adults need space to explore questions of spirit and mentors who help them to hold big questions and to think critically: competencies needed for leadership in response community needs.

In a multicampus survey of students' spiritual development, Astin et al.'s (2012) survey of 14,527 students attending 136 colleges found the following to have uniformly positive effects on selfreported college outcomes: service-learning and charitable involvement, interdisciplinary courses, study abroad, self-reflection, and meditation. Positive effects of these experiences included growth in an ethic of caring, an ecumenical worldview, and equanimity_all of which enhanced students' selfrated ability to get along with persons of races and cultures other than their own. Several studies have found that settings that support reflection and dialogue across boundaries of perceived spiritual, racial, and ethnic differences are particularly important for the development of young adults' commitments, particularly when taking place in work-based learning and service-learning experiences (Bowman, 2010; Daloz, Keen, Keen, \& Parks, 1996; Diaz \& Perrault, 2010; Goodman \& Bowman, 2014; Keen, 2010b; Keen \& Hall, 2008, 2009; King, Baxter Magolda, Barber, Brown, \& Lindsay, 2009; Seifert, Bowman, Wolniak, Rockenbach, \& Mayhew, 2017).

\section{Research Question}

The purpose of this research was to explore how participation in a postcollege year-long servicelearning program impacted emerging adults. The research question is as follows:

Research Question: What is the impact of a postcollege year of service-learning? 


\section{Methods}

This section includes a description of participants and settings, their demographic characteristics, and data sources. Principal component analysis (PCA) was used to explore data collected for this two-phase, 1-year cohort study of 689 entering and exiting participants in 18 VEV programs.

\section{Participants}

Entering volunteers $(n=798)$ and exiting volunteers $(n=698)$ who completed the survey were involved in one of the 18 programs associated with VEV, a collaborative network of denominationally based programs mostly situated in the United States and previously funded by the Lilly Endowment, Inc., through the Forum for Theological Exploration. Funding for volunteer stipends also came from worksite AmeriCorps stipends, denominational support, local support committees, alumni, and volunteers' fundraising efforts. Volunteers heard about VEV programs from previous volunteers, program recruiters, and web searches and were encouraged to participate by friends, family, parents, former volunteers, or their clergy or congregation. When entering their yearlong program, $52 \%$ of the participants were between 21 and 22 years old, and $82 \%$ were between 21 and 24 years old; remaining participants were either ages $18-20$ or 25 or older.

VEV volunteers worked and served communities in full-time positions, receiving a stipend that required a simple lifestyle and pooling of resources. Volunteers often lived together in groups of four to six, a lifestyle which provided additional opportunities for formal and informal reflection. Their volunteer work could be characterized as service-learning, similar to cocurricular service-learning in a college setting, because they were engaged in regular reflection and learning activities, guided by VEV program directors. Volunteers also had opportunities to discern their vocational and spiritual callings at retreats and with peers, program administrators, and site supervisors. A distinct focus of the VEV network was supporting $5-10 \%$ of participants who were considering leadership in the church, in recognition of the need for infusion of youthful leadership and the potential of churches to support needed change in communities.

Surveys were designed to help program directors determine effective means of assisting participants in making future vocational, service, civic, and faith choices. Eighty percent of volunteers responded to both phases of the 2012-2013 cohort survey: 798 entering volunteers and, 11 months later, 698 exiting volunteers. The response rate was high because program directors, at the request of the national VEV collaboration, administered surveys to participants starting and completing their year of service typically during program orientation and year-end retreats. A paper-and-pencil survey option was completed by $70 \%$ of volunteer participants, collected confidentially and mailed to the evaluators for analysis; another $30 \%$ of volunteers completed the survey online. As evidence of external validity, we compared the demographic profile of entering VEV participants with the profile of the U.S. population of emerging adults in regard to education, gender, race and ethnicity, religious identification, work experience, college and career aspirations. In summary, we found VEV participants were more likely to be female (70\%), White, college educated, and Catholic. A similar dominance of female participation (71\%) was found among AmeriCorps members who started in 1999 and were followed in an 8-year longitudinal study (Corporation for National and Community Service, Office of Research and Policy Development, 2008; Ward, 2014). The Corporation for National and Community Service's (2006) study of college students who volunteered also found females were overrepresented in all age groups of volunteers. However, analysis of VEV survey data between 2005 
and 2011 found no differences between genders, religious or spiritual identification, or racial and ethnic groups in responses to survey questions. Results of Arnett and Schwab's (2012) Clark University Poll of Emerging Adults also held across gender.

VEV participants were also more likely than their peers to have traveled, lived, or studied outside the United States and to identify with two or more racial or ethnic identities. Over $60 \%$ of volunteers planned to attend graduate school compared to $18 \%$ of all college graduates (Adams, 2013). Volunteers entered VEV programs with some work experience, mostly in part-time jobs (81\%) or service or internship work (81\%). Similar to $50 \%$ of youth who are employed (U.S. Bureau of Labor, 2013), almost half (48\%) of VEV participants had worked full-time before their year of service. Upon entering a VEV program, the most common of career interest areas selected by at least $40 \%$ of the participants (who could select multiple interests) were traditional academic disciplines, social work, community development, and education.

\section{Data Sources and Analysis}

To address the research questions, we analyzed entering and exiting surveys of the most recently available data from the 2012-2013 program year. Responses from 2012-2013 cohort participants were similar to survey results from the previous 7 years of evaluations. We focused on opportunities that were motivating and were important to VEV volunteers, as expressed on entering (Phase 1) and exiting (Phase 2) surveys, thus allowing for a 1-year cohort analysis in two phases. Survey development began in 2005 with interviewing program directors and participants at national program retreats in a collaborative model of evaluation (Patton, 2008). Survey questions had been honed over the years to better represent aspects of the programs and increase the validity of survey items and results.

PCA was used to reduce the 15 survey items regarding opportunities important about the VEV program into meaningful components using SPSS software. The 15 survey items, rated on a 5 -point scale, ranging from 1 (not important) to 5 (most important), were used to measure participants' perceptions of what motivated them as they entered and exited their year of service.

Initial components were easily interpreted so rotation was not performed, as unrotated solutions maximize the sum of squared component loadings, creating a set of components "that explain as much of the variance in the original variables as possible" (Rovai, Baker, \& Ponton, 2012, p. 421). The amount explained was reflected in the sum of the eigenvalues of all factors in each component. Because fair loadings of .45 or greater were theoretically interpretable, they were included into the components (Rovai et al., 2012, p. 424).

\section{Limitations and Assumptions}

The study's conclusions are limited by the self-selected nature of the sample of VEV participants and their self-reported perceptions. However, the response rate of $80 \%$ suggests that survey responses are representative of all VEV program participants. The analysis of the demographic character of the participants helped us to determine to what extent the results might be generalizable outside of the self-selected VEV population. Survey administration allowed anonymity and thus reduced participants' inclination to provide the "right" answer. 


\section{Findings and Discussion}

Findings of this two-phase cohort study are presented to address the research question, "What is the impact of a postcollege year of service-learning?" A summary of opportunities that motivated postcollege students to enter a year of voluntary service is presented first (Phase 1). Then, a summary of opportunities important for existing volunteers is presented (Phase 2). A comparison of motivating and important opportunities provides an indication of the impact of the postcollege year of service-learning.

In brief, we found programs had an impact on the importance of working for social justice for volunteers. Working selflessly for social justice did not motivate entering volunteers, but was an important opportunity for exiting volunteers. Responses to open-ended questions on the survey elucidate quantitative findings.

\section{Phase 1: Motivations to Enter a Year of Voluntary Service}

Entering VEV participants were asked to indicate, on a 5-point scale, the importance of 15 different opportunities for motivating them to do a year of voluntary service. Communalities resulting from PCA analysis of the entering survey were all at least .457, indicating that each of these 15 survey items shared common variance with other items. Based on an eigenvalue of 1 , four components were extracted. Together, the four components explained $57 \%(\lambda=12.4)$ of the total variance among 15 opportunities and were characteristically named. Table 1 includes the four motivating components along with loadings and communalities. We characterized the four Phase 1 entering cohort components as follows:

- dialogue and discover self in relationship to community,

- discern spiritual calling,

- explore career options, and

- not friendships and social life.

\section{Dialogue and discover self in relationship to community}

Component 1 for entering volunteers explained almost one third $(31 \% ; \lambda=6.2)$ of the variance accounted for by all four components (57\%). We characterized Component 1 as "dialogue and discover self in relationship to community." Community refers both to the community among volunteers and to the community members at VEV service sites. Thirteen of the 15 variables loaded into Component 1. Two variables, "explore career options" and "develop spiritually," did not load into Component 1 , but did load in Components 2 and 3, accounting for all 15 variables (see Table 1).

The 13 most important opportunities that motivated participants to complete a year of service and that loaded into Component 1 of the PCA for the entering volunteer cohort were well aligned with VEV program purposes: volunteers anticipated sustained reflection and dialogue; opportunities for friendship, social life, and shared living; finding like-minded people with whom they could dialogue; and working with people who are different from themselves. They hoped to discover things about themselves; find work matching their personality, skills, and training; find expressions of their compassion; be an effective social change agent; and gain a mature perspective on the difficulty of bringing about social change. Component 1, dialogue and discover self in relationship to community, is reflected in one entering volunteer's comment on the survey: "I want to be connected to a community that lives more like the rest of the citizens of the world." 
Table 1. Entering 2012-2013 Cohort: Results of Unrotated Principal Component Analysis, Motivating Opportunities $(\mathrm{n}=798$ )

\begin{tabular}{|c|c|c|c|c|c|}
\hline & \multicolumn{4}{|c|}{ Component } & \multirow[b]{2}{*}{ Communality } \\
\hline & $\begin{array}{l}\text { 1. Dialogue and } \\
\text { discover self in } \\
\text { relationship to } \\
\text { community }\end{array}$ & $\begin{array}{l}\text { 2. Discern } \\
\text { spiritual } \\
\text { calling }\end{array}$ & $\begin{array}{l}\text { 3. Explore } \\
\text { career } \\
\text { options }\end{array}$ & $\begin{array}{c}\text { 4. Not } \\
\text { friendships } \\
\text { and social } \\
\text { life }\end{array}$ & \\
\hline $\begin{array}{l}\text { Discover and express } \\
\text { individual gifts and } \\
\text { skills }\end{array}$ & .661 & .033 & .187 & -.391 & .626 \\
\hline Reflection and dialogue & .641 & .098 & -.231 & -.293 & .559 \\
\hline $\begin{array}{l}\text { Find expressions of my } \\
\text { compassion }\end{array}$ & .647 & .118 & -.226 & -.160 & .509 \\
\hline $\begin{array}{l}\text { Be an effective social } \\
\text { change agent }\end{array}$ & .612 & -.402 & -.118 & .316 & .656 \\
\hline $\begin{array}{l}\text { Work with people who } \\
\text { are different from me }\end{array}$ & .605 & -.067 & -321 & .001 & .474 \\
\hline $\begin{array}{l}\text { Find work matching my } \\
\text { personality, skills, } \\
\text { training }\end{array}$ & .621 & -.205 & .496 & -.167 & .702 \\
\hline $\begin{array}{l}\text { Friendships and social } \\
\text { life }\end{array}$ & .570 & -.152 &. .072 & -.464 & .568 \\
\hline $\begin{array}{l}\text { Help a community } \\
\text { address its challenges } \\
\text { and needs }\end{array}$ & .596 & -.216 & -.253 & .345 & .585 \\
\hline Work for social justice & .586 & -.385 & -.296 & .293 & .665 \\
\hline $\begin{array}{l}\text { Explore the direction of } \\
\text { my vocation or calling }\end{array}$ & .594 & .185 & .549 & .168 & .716 \\
\hline Community service & .551 & -.081 & -.298 & .085 & .405 \\
\hline Develop spiritually & .478 & .646 & -.186 & -.135 & .699 \\
\hline Explore career options & .467 & -.230 & .678 & .257 & .796 \\
\hline $\begin{array}{l}\text { Discover what God } \\
\text { desires for my life }\end{array}$ & .313 & .812 & .012 & .156 & .781 \\
\hline $\begin{array}{l}\text { Explore a calling to the } \\
\text { ministry }\end{array}$ & .239 & .722 & .081 & .373 & .724 \\
\hline
\end{tabular}

Note: Bold variables are those with component loadings $>.45$.

\section{Discern spiritual calling}

Component 2 of entering volunteers' motivations, which we characterized as "discern spiritual calling," explained $11 \%(\lambda=2.2)$ of the total $(57 \%)$ variance. Three variables loaded into Component 2 and measured volunteers' motivation to find a calling to the ministry, discover what God desires for their lives, and develop spiritually. Similar to Component 1, Component 2 loadings also align with the VEV purpose of exposing emerging adults to ministerial work: Over the last 8 years of VEV program evaluations, $5-10 \%$ of entering volunteers expressed interest in the ministry. For instance, one 24-year-old male volunteer wrote, "Vocational discernment should be a continuous journey because the pathways that you see may not be the pathways God sees. If you see yourself at the end of a journey, God may see it as a beginning." 


\section{Explore career options}

Component 3 of the entering volunteer cohort explained $8 \%(\lambda=1.6)$ of the variance. We characterized the third component as "exploring career options." The three survey items loaded into this component indicated the importance of exploring career options, exploring the direction of vocation or calling, and finding work matching personality, skills, and training. These opportunities surfaced as opportunities important for VEV participants even though program materials did not stress a focus on career exploration. For example, the writing of one volunteer illustrates this proposition: "This year is my deliberate way to take time to thoughtfully consider my vocation and next career steps and I hope it will be fruitful!"

\section{Not friendships and social life}

Component 4 explained $7 \%(\lambda=1.4)$ of the variance with a single variable which loaded negatively: Upon entering one of VEV programs, some volunteers negated the importance of the opportunity for friendships and social life. Another variable which was close to meeting the loading criterion of .45 affirmed the "opportunity to help a community address its challenges and needs." These two variables together indicate that participants enter the program desiring to do something for others and not for friendships and social life. As one volunteer wrote, "I expect to be stretched and have the flexibility that will allow God to reveal what my calling is beyond my personal plans and expectations."

\section{Phase 2: Opportunities Important for Exiting Volunteers After Their Year of Service}

Eleven months after entering the VEV program, volunteers responded to the second phase of data collection on a survey upon exiting the program. The survey included the same 15 variables used on the entering survey to measure opportunities exiting volunteers considered important during their year of service. Table 2 shows results of PCA analysis with unrotated component loadings and communalities. Communalities were equal to or greater than .396, confirming that each of the 15 survey items shared common variance with other items. Fifty-nine percent of the variance was explained by four components $(\lambda=8.8)$. All but one variable loaded into one of the four components. We characterized these four Phase 2 exiting cohort components as follows:

- work as an expression of compassion, skills, and spirit;

- work for social justice outside of religion and spirituality;

- career exploration; and

- friendships and social life. 
Table 2. Exiting 2012-2013 cohort: Results of Unrotated Principal Component Analysis, Important Opportunities $(\mathrm{n}=698)$

\begin{tabular}{|c|c|c|c|c|c|}
\hline & \multicolumn{4}{|c|}{ Component } & \multirow[b]{2}{*}{ Communality } \\
\hline & $\begin{array}{l}\text { 1. Work as } \\
\text { an } \\
\text { expression of } \\
\text { compassion, } \\
\text { skills, and } \\
\text { spirit }\end{array}$ & $\begin{array}{l}\text { 2. Work for } \\
\text { social } \\
\text { justice } \\
\text { outside of } \\
\text { religion and } \\
\text { spirituality }\end{array}$ & $\begin{array}{l}\text { 3. Career } \\
\text { exploration }\end{array}$ & $\begin{array}{l}\text { 4. Friend- } \\
\text { ships and } \\
\text { social life }\end{array}$ & \\
\hline $\begin{array}{l}\text { Find expressions of } \\
\text { compassion }\end{array}$ & .672 & .057 & -.236 & .082 & .517 \\
\hline $\begin{array}{l}\text { Discover individual gifts and } \\
\text { skills }\end{array}$ & .671 & .036 & .241 & .046 & .512 \\
\hline Develop spiritually & .642 & -.536 & -.204 & .067 & .745 \\
\hline $\begin{array}{l}\text { Be an effective social change } \\
\text { agent }\end{array}$ & .611 & .467 & -.154 & -.166 & .643 \\
\hline $\begin{array}{l}\text { Discover what God desires for } \\
\text { my life }\end{array}$ & .605 & -.610 & -.034 & -.107 & .751 \\
\hline $\begin{array}{l}\text { Explore a calling to the } \\
\text { ministry }\end{array}$ & .598 & -.183 & .478 & -.121 & .634 \\
\hline Reflection and dialogue & .527 & -.233 & -.257 & .415 & .569 \\
\hline $\begin{array}{l}\text { Find work matching } \\
\text { personality, skills, training }\end{array}$ & .514 & .302 & .453 & .066 & .565 \\
\hline $\begin{array}{l}\text { Help community address } \\
\text { challenges and needs }\end{array}$ & .487 & .319 & -.040 & -.359 & .469 \\
\hline $\begin{array}{l}\text { Work with people who are } \\
\text { different than me }\end{array}$ & .470 & .250 & -.281 & .184 & .396 \\
\hline Work for social justice & .450 & .523 & -.347 & -.001 & .597 \\
\hline $\begin{array}{l}\text { Explore a calling to the } \\
\text { ministry }\end{array}$ & .448 & -.594 & -.010 & -.238 & .634 \\
\hline Explore career options & .398 & .208 & .669 & -.161 & .675 \\
\hline Community service & .364 & .167 & -.434 & .333 & .460 \\
\hline Friendships and social life & .345 & 164 & .182 & .689 & .654 \\
\hline
\end{tabular}

Note: Bold variables are those with component loadings $>.45$.

Found work as an expression of compassion, skills, and spirit. All but three of 15 variables loaded in exiting volunteers' Component 1 and explained $28 \%(\lambda=4.2)$ of the total variance accounted for by all four components (59\%). We named this component "found work as an expression of compassion, skills, and spirit." Two of the three variables that did not load in exiting volunteer Component 1 loaded into the other three components. After a year of service, VEV participants considered expressions for their compassion, discovering individual gifts and skills, developing spiritually, being an effective social change agent, and discovering what God desires for their life as important opportunities. One volunteer wrote, "When I described my options for next year in a dialogue with other volunteers as well as my sense of a call, I was able to recognize where my passions are." Another volunteer felt the program had a dramatic impact on her life, writing, 
This year has changed me completely. I came into the year with no direction in my life and feeling like I was going to have to spend the rest of my life in the rat race that is the American dream. I quickly realized that I was surrounded by other people who had the same fears and together we have discovered another way with a different definition of success. I now have enough direction in my life to know that I am being called to a life of service and ministry in some aspect for as long down the road as I can see.

Work for social justice outside of religion and spirituality. Component 2 of exiting volunteers' responses explained another $13 \%(\lambda=2.0)$ of the total $59 \%$ of variance accounted for by 15 variables measuring opportunities important of VEV participants. Four variables loaded into Component 2, one positively and three negatively. Loading positively into Component 2 was the variable reflecting the importance of being an effective social change agent. Loading negatively into Component 2 were three variables: developing spiritually, discovering what God desires for my life, and exploring a calling to the ministry.

Program directors have reported that their volunteers have expressed high general satisfaction with VEV programs that not only serve emerging adults who are considering ministerial work, but also serve emerging adults who are not considering ministerial work. Common among those groups considering and not considering ministerial work after volunteering for a year is the importance of being an effective social change agent. One volunteer's comments illustrate Component 2:

I came into this year [of service] with no idea about what I wanted to do with my next year or in general in my life. I have learned a lot of skills for direct service and that I am very passionate about social justice. I believe this is my calling and I want to continue to be educated and get a career in social work.

\section{Career exploration}

The third component of PCA for exiting volunteers, career exploration, suggests exiting VEV participants regarded being able to explore issues related to work. This importance is evidenced by the $10 \%(\lambda=1.55)$ of the total variance $(59 \%)$ explained by the communalities of three variables: explore career options, explore a calling to the ministry, and find work matching one's personality, skills, and training. One volunteer reported learning "ways to approach the discernment process which I will be able to use in the future."

\section{Friendships and social life}

In the last of the four components for exiting volunteers, one item explained $7 \%(\lambda=1.55)$ of the total $59 \%$ of total variance explained by all four components in Phase 2 of data collected from the cohort. Friendships and social life are a powerful and distinct element of exiting participants' reflections on their year-long experience and are not related to programmatic, instrumental objectives, nor keenly anticipated by volunteers when entering their year of service (see Table 3). A participant's comment captures the fourth component: "I learned that it almost does not matter what I am doing career wise...I have learned to be less concerned about the details of a job and more concerned about developing as a person and building relationships." 


\section{Shifts in Motivations and Important Opportunities for Entering and Exiting Volunteers}

Comparing the dominant components of volunteers' motivations, we found volunteers entered motivated to seek opportunities for dialogue and discovery about themselves in relationship to community and callings. Upon exiting, volunteers found opportunities to express themselves compassionately in work for social justice while exploring careers and building friendships and social life.

The opportunities motivating entering volunteers illustrated in the second component of Phase 1, which we characterized as discern spiritual calling, were not distinctly important in Phase 2. Instead, spirituality was just one of the 12 variables that loaded into Component 1 in Phase 2 . A focus on working for social justice was an opportunity important for exiting volunteers but was not in any of the components based on entering volunteers' responses. Table 3 provides a ranking of the components from the two PCA analyses of responses measured when volunteers entered and exited the program and illustrates the shifting of opportunities motivating and important to volunteers before and after their year of service.

Table 3. 2012-2013 Cohort: Comparison of Motivating and Important Components for Entering $(\mathrm{n}=798)$ and Exiting $(\mathrm{n}=698)$ Volunteers

\begin{tabular}{lcccc}
\hline $\begin{array}{l}\text { Principal } \\
\text { Component } \\
\text { Analysis }\end{array}$ & $\begin{array}{c}\text { Entering Volunteers' } \\
\text { Motivating } \\
\text { Opportunities } \\
\text { (Phase 1) }\end{array}$ & $\begin{array}{c}\text { \% Variance } \\
\text { Explained } \\
\text { (Total 57\%) }\end{array}$ & $\begin{array}{c}\text { Exiting Volunteers' } \\
\text { Important } \\
\text { Opportunities } \\
\text { (Phase 2) }\end{array}$ & $\begin{array}{c}\text { \% Variance } \\
\text { Explained } \\
\text { (Total 59\%) }\end{array}$ \\
\hline Component 1 & $\begin{array}{c}\text { Dialogue and discover } \\
\text { self in relationship to } \\
\text { community }\end{array}$ & $31 \%$ & $\begin{array}{c}\text { Work as an expression } \\
\text { of compassion, skills, } \\
\text { and spirit }\end{array}$ & $28 \%$ \\
Component 2 & $\begin{array}{c}\text { Discern spiritual } \\
\text { calling }\end{array}$ & $11 \%$ & $\begin{array}{c}\text { Work for social justice } \\
\text { outside of religion and } \\
\text { spirituality }\end{array}$ & $13 \%$ \\
Component 3 & Explore career & & Career exploration & $10 \%$ \\
Component 4 & Not about social life & $7 \%$ & Friendships and social & $7 \%$ \\
\hline
\end{tabular}

\section{Interpretation of Findings}

Notable in the findings is the lack of importance for the opportunity to do "community service," one of the 15 survey variables. Community service did not load into any of the Phase 2 components important to exiting volunteers and loaded, among 12 other variables, only into the first of four components in analysis of entering volunteers. Social justice emerged as a concept more salient than community service for exiting volunteers, having loaded into two of four components. Perhaps the label "community service" does not capture the breadth and depth of what is important by volunteers and working for social justice does. One explanation might be that community service was something 
emerging adult volunteers had already done in college and now they are embarking upon a more meaningful quest of social justice by serving an entire year as a volunteer. Another explanation is that an entire year of service might expose volunteers to the difficulties of effecting meaningful change in communities, one deserving of recognition as work in a context larger than community service and in the realm of affecting social justice. Whatever the explanation, community service and service-learning administrators may consider that an emerging adult may be thinking, "I am not just here to do a little community service; I am here to find how my identity is associated with work for social justice."

We also found career exploration to be an instrumental concern represented by the third component for both entering and exiting volunteers. This finding reinforces the proposition that emerging adults are on a quest to find a career path (Arnett, 2014; Parks, 2011). The VEV had supported young adults who come from diverse backgrounds to explore the relationship between faith and work during a year of service. The quest of the entering volunteers to explore what God discovers for their life, reflected in Component 1 of entering volunteers' motivations seems to be embedded in exiting volunteers' quest for a larger search for an expression of one's compassion, skills, and spirituality.

Emerging adults leaving college have sought yearlong volunteer opportunities for experiences that may help them explore their spirituality and career callings, particularly in a setting that offers both challenges and supports for growth. These findings confirm Parks' (2011) theory that emerging adulthood is characterized by a search for meaning and an exploration of big questions in forming worthy dreams. Findings also confirm those of Arnett and Schwab's (2012) Clark University Poll of Emerging Adults regarding the aspects of emerging adulthood that make it a unique stage of life: a stage in which 1 year can shift priorities, as also found by Magolda (2009). Findings also affirm Astin et al.'s (2012) demonstration that many college students are hungry for spiritual reflection. Colleges and universities as well as postcollege service programs may do well to make programmatic time for reflection, including spiritual reflection. VEV programs and other work-based learning programs may create a unique opportunity to support emerging adults' vocational and spiritual reflection by including formal and informal reflection at service sites or with housemates and providing dialogue and reflection across boundaries of perceived difference among volunteers, as well as with clients and supervisors at service sites (Keen \& Hall, 2008; 2009; Mitchell et al., 2015; Richard et al., 2016).

\section{Recommendations for Research and Action}

Future research can follow volunteers several years after completion of the program. One of the VEV programs, Jesuit Volunteer Corps, has followed their alumni and hosted reunions and retreats and heard self-reports of the lifelong importance of the year. The program is nicknamed "ruined for life," implying that the program changed life choices in a lasting way. Studies of Peace Corps volunteers have also found lasting impact (Lough, Sherraden, McBride, \& Xiang, 2014). In Ward's (2014) personal communication, he expressed hope that the Corporation for National Service would continue the longitudinal study of AmeriCorps volunteers from which he drew his analysis of three waves of data: at entrance, 1 year, and at 8 years. Eight years after service, AmeriCorps Volunteers were aware of civic and committed to public interests. In 1 year of service, volunteers in the VEV programs focused their callings, discovered new gifts and skills, and developed spiritually while becoming effective social change agents. 


\section{Endorse postcollege volunteer opportunities}

College career counselors and other influencers can recommend year-long, postcollege servicelearning programs for opportunities they provide and use opportunities which motivate volunteers to encourage participation. Intentionally designed work-based learning experiences and servicelearning programs have the potential to accelerate development through the emerging adulthood years, to prepare more adults for meaningful careers, and to engage them in a life of service to their communities.

\section{Allow and create time for reflection}

We recommend that opportunities for spiritual reflection and spiritual direction be more available to emerging adults in their context of their work and service. Reflective interaction with mentors, peers, site supervisors, friends, and family was important for VEV and may be a need among nonvolunteers in work settings. Retreats, informal interactions, and formal dialogue sessions can create space for discovery and decision-making among emerging adults. One practice effective at VEV retreats was the clearness committee, adapted from Quaker practice (Palmer, 2013).

\section{Deliver more effective programming}

For directors of yearlong volunteer and other service programs that engage emerging adults, this research provides insight into participants' motivations and the opportunities they value. With this insight, directors might become more effective meeting their volunteers' needs and, hence, community needs. Ultimately, there is a potential to increase the number of emerging young adult professionals who find meaning and purpose in work advancing communities and social justice for positive social change.

\section{References}

Adams, S. (2013, May 3). College graduates expectations are out-of-line with reality says study. Forbes. Retrieved from http://www.forbes.com/sites/susanadams/2013/05/02/collegegraduates-expectations-are-out-of-line-with-reality-says-study/

Arnett, J. J. (2000). Emerging adulthood: A theory of development from the late teens through the twenties. American Psychologist, 55, 469-480. doi:10.1037/0003-066X.55.5.469

Arnett, J. J. (2004). Emerging adulthood: The winding road from the late teens through the twenties. New York, NY: Oxford University Press.

Arnett, J. J. (2014). Presidential address: The emergence of emerging adulthood: A personal history. Emerging Adulthood, 2, 155-162. doi:10.1177/2167696814541096

Arnett, J. J., \& Schwab, J. (2012). Clark University poll of emerging adults: Thriving, struggling, hopeful. Retrieved from http://www2.clarku.edu/clark-poll-emerging-adults/pdfs/clarkuniversity-poll-emerging-adults-findings.pdf

Astin, A. W., Astin, H. W., \& Lindholm, J. A. (2012). Cultivating the spirit: How college can enhance students'inner lives. San Francisco, CA: Jossey-Bass/Wiley Publishers.

Bowman, N. A. (2010). College diversity experiences and cognitive development: A meta-analysis. Review of Educational Research, 80, 4-33. doi:10.3102/0034654309352495 
Bowman, N. A. (2011). Promoting participation in a diverse democracy: A meta-analysis of college diversity experiences and civic engagement. Review of Educational Research, 81, 29-68. doi:10.3102/0034654310383047

Campbell, M., \& Zegwaard, K. E. (2015). Developing critical moral agency through workplace engagement. In M. Kennedy, S. Billett, S. Gherardi, \& L. Grealish (Eds.), Practice-based learning in higher education (pp. 47-64). Dordrecht, The Netherlands: Springer.

Celio, C. I., Durlak, J., \& Dymnicki, A. (2011). A meta-analysis of the impact of service learning on students. Journal of Experiential Education, 34, 164-181. doi:10.5193/JEE34.2.164

Conway, J., Amel, E., \& Gerwien, D. (2009). Teaching and learning in the social context: A metaanalysis of service learning's effects on academic, personal, social, and citizenship outcomes. Teaching of Psychology, 36, 233-245. doi:10.1080/00986280903172969

Corporation for National and Community Service. (2006). College students helping America. Retrieved from http://www.nationalservice.gov/sites/default/files/ documents/06_1016_rpd_college_full.pdf

Corporation for National and Community Service, Office of Research and Policy Development. (2008). Still serving: Measuring the eight-year impact of AmeriCorps on alumni. Washington, DC: Author.

Crews, R. (2013). Guide to college and university service learning programs. Retrieved October 7, 2013, from http://evergreen.loyola.edu/rcrews/www/sl/academic.html

Daloz, L., Keen, C., Keen, J., \& Parks, S. (1996). Common fire: Leading lives of commitment in a complex world. Boston, MA: Beacon Press.

Diaz, A., \& Perrault, R. (2010, Fall). Sustained dialogue and civic life: Postcollege impacts. Michigan Journal of Community Service Learning, 17, 32-43. Retrieved from http://hdl.handle.net/2027/spo.3239521.0017.103

Forum for Theological Exploration. (2014). Faith-based volunteer organizations. Retrieved November 6, 2014, from http://fteleaders.org/networks/faith-based-volunteer-organizations

Goodman, K. M., \& Bowman, N. A. (2014). Making diversity work to improve college student learning. New Directions for Student Services, 2014, 37-48. doi:10.1002/ss.20099

Keen, C. (2010a). Measuring dialogue across difference as a civic skill. Journal of College and Character, 11, 1. doi:10.2202/1940-1639.1018

Keen, C. (2010b). New longitudinal study of Teach for America alumni's civic engagement: What's enough of what kind of engagement? Journal of College and Character, 11, 7. doi:10.2202/1940-1639.1269

Keen, C., \& Hall, K. (2008). Postgraduation service and civic outcomes for high financial need students of a multi-campus, co-curricular service learning college program. Journal of College and Character, 10, 2. doi:10.2202/1940-1639.1066

Keen, C., \& Hall, K. (2009). Engaging with difference matters: Longitudinal college outcomes of 25 co-curricular service learning programs. Journal of Higher Education, 80, 59-79. Retrieved from http://bonnernetwork.pbworks.com/f/Keen+\%26+Hall+JHE+Jan.-Feb.09.pdf 
King, P. M., Baxter Magolda, M. B., Barber, J. P., Brown, M. K., \& Lindsay, N. K. (2009). Developmentally effective experiences for promoting self-authorship. Mind, Brain, and Education, 3, 108-118. doi:10.1111/j.1751-228X.2009.01061.x

Lough, B. J., Sherraden, M. S., McBride, A. M., \& Xiang, X. (2014). The impact of international service on the development of volunteers' intercultural relations. Social Science Research, 46, 48-58. doi:10.1016/j.ssresearch.2014.02.002

Magolda, M. B. B. (2004). Making their own way: Narratives for transforming higher education to promote self-development. Herndon, VA: Stylus Publishing, LLC.

Magolda, M. B. B. (2008). Three elements of self-authorship. Journal of College Student Development, 49, 269-284. Retrieved from http://ezp.waldenulibrary.org/login?url=https://search-proquestcom.ezp.waldenulibrary.org/docview/195178809?accountid=14872

Magolda, M. B. B. (2009). Authoring your life: Developing an internal voice to navigate life's challenges. Sterling, VA: Stylus.

Mitchell, T. D., Battistoni, R. M., Keene, A. S., \& Reiff, J. (2013). Programs that build civic identity: A study of alumni. Diversity and Democracy, 16, 22-23.

Mitchell, T. D., Richard, F. D., Battistoni, R. M., Rost-Banik, C., Netz, R., \& Zakoske, C. (2015). Reflective practice that persists: Connections between reflection in service-learning programs and in current life. Michigan Journal of Community Service Learning, 21, 49-64.

Murphy, K. A., Blustein, D. L., Bohlig, A. J., \& Platt, M. G. (2010). The college-to-career transition: An exploration of emerging adulthood. Journal of Counseling \& Development, 88, 174-181.

Palmer, P. (2013). The clearness committee: A communal approach to discernment. Retrieved from http://www.couragerenewal.org/parker/writings/clearness-committee

Parks, S. (2011). Big questions, worthy dreams: Mentoring emerging adults in their search for meaning, purpose, and faith. San Francisco, CA: Jossey Bass.

Patton, M. (2008). Utilization-focused evaluation. Thousand Island, CA: Sage Publications.

Richard, D., Keen, C., Hatcher, J., \& Pease, H. (2016, Fall). Pathways to adult civic engagement: Benefits of reflection and dialogue across difference in college service-learning programs. Michigan Journal of Community Service Learning, 23. 1. doi:10.3998/mjcsloa.3239521.0023.105

Rovai, A., Baker, J., \& Ponton, M. (2012). Social science research design and statistics: A practitioner's guide to research methods and SPSS analysis. Chesapeake, VA: Watertree Press.

Seifert, T. A., Bowman, N. A., Wolniak, G. C., Rockenbach, A. N., \& Mayhew, M. J. (2017). Ten challenges and recommendations for advancing research on the effects of college on students. AERA Open. Advance online publication.

U.S. Bureau of Labor. (2013, August 20). Employment and unemployment among youth summary. Retrieved from http://www.bls.gov/news.release/youth.nr0.htm

Voices for Service. (2012). National service: Providing pathways to employment. Retrieved from http://voicesforservice.org/resources/PathwaysReport.pdf 
Ward, K. D. (2014). Cultivating public service motivation through AmeriCorps service: A longitudinal study. Public Administration Review, 74, 114-125. doi:10.1111/puar.12155

Warren, J. L. (2012). Does service-learning increase student learning? A meta-analysis. Michigan Journal of Community Service Learning, 18, 56-61.

Zegwaard, K. E., \& Coll, R. K. (2011). Using cooperative education and work-integrated education to provide career clarification. Science Education International, 22, 282-291.

The Journal of Social Change, sponsored by Walden University, welcomes manuscripts focusing on interdisciplinary research in social change that improves the human condition and moves people, groups, organizations, cultures, and society toward a more positive future.

Walden University Publishing: http://www.publishing.waldenu.edu 